\title{
POSTERIOR URETHRAL VALVE AND PRENATALY RESOLVED MULTICYSTIC DYSPLASTIC KIDNEY
}

\author{
Natasha Aluloska ${ }^{1}$, Snezana Palchevska ${ }^{2}$, \\ Risto Simeonov ${ }^{2}$, Zoran Gucev ${ }^{1}$, Velibor Tasic ${ }^{1}$ \\ ${ }^{1}$ University Children's Hospital, Medical Faculty Skopje, RN Macedonia \\ ${ }^{2}$ Clinical Hospital Adzibadem Sisitna, Skopje, RN Macedonia
}

Corresponding author: Natasha Aluloska MD, PhD, Neonatology Department, University Children's Hospital, Vodnjanska 17, 1000 Skopje, Republic of North Macedonia. Tel: +389-71-353366, Fax: +389-2-3233067, E-mail: aluloska@gmail.com

\section{ABSTRACT}

Multicystic dysplastic kidney is a rare congenital anomaly of the kidney and urinary tract. The association with the posterior urethral valve is also very rare. Here we present a patient with both entities and prenatal resolution of the cysts.

A 10-week old baby was referred for nephrourological work up due to prenatal diagnosis of the left multicystic kidney. He had serial US scans during the pregnancy. Immediately before delivery the cysts were not seen (prenatal resolution). There were no extrarenal anomalies. The first postnatal ultrasound scan revealed normal sized right kidney without dilatation of the pelvicalyceal system. The bladder had normal thickness of the wall. Technetium-99m dimercaptosuccinic acid scan showed no activity on the left side, and the right kidney appeared normal. At two months of age, a poor urinary steam was observed and additional urologic work up was indicated on clinical suspicion of PUV. Voiding urethrocystography revealed posterior urethral valve and the baby underwent cytoscopic valve resection.

Conclusion: We present a rare association of two congenital anomalies of the kidney and urinary tract with prenatal involution of the multicystic dysplastic kidney that is extremely rare event as seen in our case. Presence of posterior urethral valve must be suspected in a male baby with a poor urinary stream even when his ultrasound scan of urinary system appears normal.

Keywords: kidney, dysplasia, posterior urethral valve

Abbreviations: MCDK (Multicystic dysplastic kidney), CAKUT (congenital anomaly of kidney and urinary tract), PUV (posterior urethral valve), VCUG (Voiding cystourethrogram), Tc99m DMSA (Technetium-99m dimercaptosuccinic acid)

\section{INTRODUCTION}

Multicystic dysplastic kidney (MCDK) is a rare congenital anomaly of the kidney and urinary tract (CAKUT). The disease is characterized with multiple non-communicating cysts without functional renal parenchyma. Nowadays the diagnosis is established with prenatal ultrasound screening of the kidneys and urinary tract. Postnatally, the babies present with palpable abdominal mass. Postnatal ultrasound scan and radionuclide studies are sufficient imaging studies 
to confirm the diagnosis. Association with posterior urethral valve is also very rare. Here we present a patient with both entities and what is exceptionally a rare event - prenatal resolution of the cysts.

\section{CASE REPORT}

IA 10 -week old male baby was referred for nephrourological work up due to prenatal diagnosis of the left multicystic kidney and postnatal suspicion for posterior urethral valves. Serial prenatal ultrasound examinations showed left MCDK whose cysts disappear prior to birth (prenatal resolution). There were no extrarenal anomalies. The baby was born at term by vaginal delivery. The Apgar score was 9 and 10 at 1 and 5 minutes respectively. His birth weight was 3,450 gr and the length was $53 \mathrm{~cm}$. The first postnatal ultrasound scan revealed absent left kidney and normal right kidney, ureter and urinary bladder. There was no evidence of renal tissue on the left side (Figure 1). The bladder had normal thickness of the wall. The baby had unremarkable postnatal course and was discharged from the hospital on the third postnatal day.

At two months of age, poor urinary steam was observed. It was evidenced by his pediatrician and additional urologic work up was indicated on clinical suspicion of posterior urethral valve (PUV). Repeated ultrasound scan showed an increased growth of the right kidney. The renal tissue was not evidenced on the left side nei- ther ectopically in the pelvis and the abdomen. The bladder wall appeared normal with thickness of $3 \mathrm{~mm}$ when it was full. After spontaneous voiding there was mild amount of residual urine. Voiding cystourethrogram (VCUG) revealed presence of a posterior urethral valve (Figure 2). Tc99m DMSA renal scan (Technetium-99m dimercaptosuccinic acid) showed an absent left kidney and a normal right kidney. He underwent cystoscopic valve resection.



Fig. 2. Voiding cystouretrography revealed posterior urethral valve (arrow) and left vesicoureteral reflux grade II

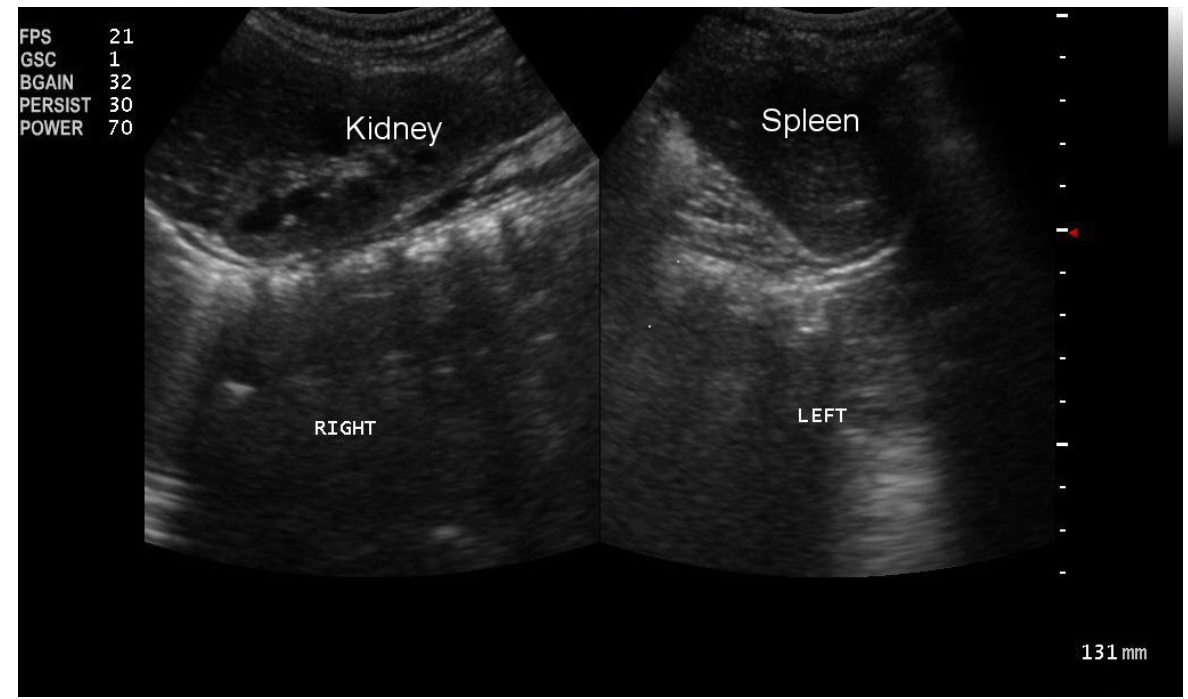

Fig. 1. Ultrasound scan does not reveal kidney tissue on the left side 


\section{DISCUSSION}

We present a rare association of multicystic dysplastic kidney (MCDK) with posterior urethral valve in a baby. The dual pathology is described only in few case reports in the literature. In the series of Mathiot et al. among 54 neonates with diagnosed MCDK three had posterior urethral valves [1]. Pooled data from 67 studies including 2159 patients in whom VCUG was performed showed association with posterior urethral valves only in 9 cases $(0.42 \%)$ [2]. The most common associated anomaly in patients with PUV was the kidney anomaly. Eight patients in a study of 98 patients with posterior urethral valves had kidney anomalies (multicystic kidney disease and renal agenesis/dysplasia) [3].

In the past the babies with MCDK underwent extensive urologic investigations and surgeries. Recently it has been suggested that serial ultrasound scanning is the unique and sufficient strategy for diagnosis and follow up of children with MCDK [4]. Many authors have raised questions on the utility of VCUG in children with MCDK who have a normal ultrasound scan (absence of significant pelvicalyceal dilatation) [5, 6]. Ultrasound scan cannot exclude mild grade of vesicoureteral reflux. On the other hand, mild grades of reflux do not pose risk to the single kidney. If the child has regular follow up by his/her pediatrician with awareness for febrile urinary infection, then prompt diagnosis of the urinary tract infection will be done and the risk for the renal damage will reduced [7]. In our case the baby had normal kidney and bladder ultrasound, and this in theory did not indicate performing of VCUG. Clinical observation of poor urinary stream guided us for further urologic work up. The second rare feature in this case is the prompt prenatal resolution of the cysts.

A meta-analysis of the data reported in studies on unilateral MCDK was performed by Schreuder et al. [2]. In five studies the prenatal screening revealed presence of unilateral MCDK, but on the first postnatal scan there was no evidence of renal tissue which indicated prenatal resolution of the MCDK in 21 out of 389 $(5.4 \%)$ cases $[5,6,8,9,10]$.

There are only few reports on prenatal resolution of the cysts in the kidneys which were considered as multicystic dysplastic [9, 11].
Usually, the resolution of the cysts begins in the postnatal period and, in majority of the cases, the resolution is completed by the end of the first 18 months [5]. Therefore, the surgery for MCDK is rarely indicated and a surgery before 2 years of age is usually not indicated in an asymptomatic baby $[8,10,12,13,14]$. At the University Children's Hospital in Skopje the surgical extirpation of the MCDK was indicated only in one case in the last ten years - that was a baby with extremely large MCDK which filled the whole abdomen and seriously comprised the breathing. The child has normal renal function and the growth is not impaired.

\section{CONCLUSION}

We present a patient with MCDK with PUV where the cystic component has disappeared prenatally, which is extremely rare event as seen in our case.

Posterior urethral valves should be suspected in male infants with poor urinary stream even if the kidney-ureter-bladder ultrasound scan is normal.

\section{REFERENCES}

1. Mathiot A, Liard A, Eurin D, Dacher JN. Prenatally detected multicystic renal dysplasia and associated anomalies of the genito-urinary tract. J Radiol. 2002; 83: 731-5.

2. Schreuder MF, Westland R, van Wijk JA. Unilateral multicystic dysplastic kidney: a meta-analysis of observational studies on the incidence, associated urinary tract malformations and the contralateral kidney. Nephrol Dial Transplant. 2009; 24: 1810-8.

3. Mirshemirani A, Khaleghnejad A, Rouzrokh M, Sadeghi A, Mohajerzadeh L, Sharifian M. Posterior Urethral Valves; A single Center Experience. Iran J Pediatr. 2013; 23(5): 531-535.

4. Kalisvaart J, Bootwala Y, Poonawala H, Elmore J, Kirsch A, Scherz H, Jones R, Grattan-Smith JD, Smith E. Comparison of ultrasound and magnetic resonance urography for evaluation of contralateral kidney in patients with multicystic dysplastic kidney disease. J Urol. 2011; 186: 1059-64.

5. Alconcher L, Tombesi M. Multicystic dysplastic kidney detected by prenatal ultrasonogra- 
phy: conservative management. Pediatr Nephrol 2005; 20: 1024-1025.

6. Lazebnik N, Bellinger MF, Ferguson JE, et al. Insights into the pathogenesis and natural history of fetuses with multicystic dysplastic kidney disease. Prenat Diagn 1999; 19: 418-423.

7. Mansoor O, Chandar J, Rodriguez MM, Abitbol CL, Seeherunvong W, Freundlich M, Zilleruelo G. Long-term risk of chronic kidney disease in unilateral multicystic dysplastic kidney. Pediatr Nephrol. 2011; 26: 597-603.

8. Sukthankar S, Watson AR. Unilateral multicystic dysplastic kidney disease: defining the natural history. Anglia Paediatric Nephrourology Group. Acta Paediatr 2000; 89: 811-813.

9. Aubertin G, Cripps S, Coleman G, et al. Prenatal diagnosis of apparently isolated unilateral multicystic kidney: implications for counselling and management. Prenat Diagn 2002; 22: 388-394.
10. Aslam M, Watson AR. Unilateral multicystic dysplastic kidney: long term outcomes. Arch Dis Child 2006; 91: 820-823.

11. Hayes WN, Watson AR; Trent \& Anglia MCDK Study Group. Unilateral multicystic dysplastic kidney: does initial size matter? Pediatr Nephrol. 2012; 27: 1335-40.

12. Chiappinelli A, Savanelli A, Farina A, Settimi A. Multicystic dysplastic kidney: our experience in non-surgical management. Pediatr Surg Int. 2011; 27: 775-9.

13. Krill A, Salami S, Rosen L, Friedman SC, Gitlin J, Palmer LS. Evaluating compensatory hypertrophy: a growth curve specific for solitary functioning kidneys. J Urol. 2012; 188(4 Suppl): $1613-7$.

14. Abdulhannan P, Stahlschmidt J, Subramaniam R. Multicystic dysplastic kidney disease and hypertension: clinical and pathological correlation. $\mathrm{J}$ Pediatr Urol. 2011; 7: 566-8. 


\title{
Резиме
}

\section{ВАЛВУЛА НА ЗАДНА УРЕТРА И ПРЕНАТАЛНА РЕЗОЛУЦИЈА НА МУЛТИЦИСТИЧЕН ДИСПЛАСТИЧЕН БУБРЕГ}

\author{
Наташа Алулоска ${ }^{1}$, Снежана Палчевска², \\ Ристо Симеонов ${ }^{2}$, Зоран Гучев ${ }^{1}$, Велибор Тасиќ ${ }^{1}$ \\ ${ }^{1}$ Универзитетска клиника за детски болести, Медицински факултет, Скопје, РС Македонија \\ ${ }^{2}$ Клиничка болница „Аџибадем Сиситна“, Скопје, РС Македонија
}

Мултицистичниот диспластичен бубрег е ретка конгенитална аномалија на бубрезите и на уринарниот тракт. Асоцијацијата на оваа аномалија со валвула на задната уретра е уште поретка. Во овој труд презентираме пациент со овие две аномалии и со пренатална резолуција на цистите.

Доенче на возраст од 10 недели беше упатено за нефролошка-уролошка обработка, поради пренатално дијагностициран мултицистичен лев бубрег. Во текот на бременоста направени се повеќе ултразвучни прегледи со наод на мултицистичен диспластичен лев бубрег. Непосредно пред раѓањето реализиран е ултразвучен преглед на кој цисти на левиот бубрег не се видени (пренатална резолуција). Пациентот нема екстраренални аномалии. Првиот постнатален ултразвучен преглед покажа десен бубрег со нормална големина и без дилатација на уринарниот тракт. Sидот на мочниот меур беше со нормална дебелина. Скенот со технициум99м димеркаптосукцинилна киселина не покажа никаква активност на левата страна, десниот бубрег изгледаше нормално. На возраст од две месеци добиен е податок за слаб млаз на урина при мокрење, поради што е индицирана дополнителна уролошка обработка. Реализирана е микциска уретроцистографија со наод на валвула на задна уретра, по што беше реализирана ресекција на валвулата.

Заклучок: Презентираме ретка асоцијација на две конгенитални аномалии на бубрезите и на уринарниот тракт, со пренатална инволуција на мултицистичен диспластичен бубрег, што е ектремно ретко. Клиничарите треба да се посомневаат на валвула на задна уретра кај доенчиња со тенок и прекинат млаз на урина дури и кога ултразвучниот наод на бешиката е уреден.

Клучни зборови: бубрег, дисплазија, валвула на задна уретра 